\title{
MERAWAT RUHANI JEMAAH: STUDI DAKWAH MAJELIS TAKLIM DI DESA PANGEDARAN, KABUPATEN SAROLANGUN, PROVINSI JAMBI
}

\author{
As'ad \\ UIN Sulthan Thaha Saifuddin Jambi \\ Email: asadisma@uinjambi.ac.id \\ Muhammad Rafii \\ STAI Ahsanta Jambi \\ Email:arrafii1995@gmail.com
}

\author{
Abdurahman Syayuthi \\ STAI Ahsanta Jambi \\ Email:syayuthia@gmail.com

\section{Fahmi Rohim} \\ STAI Ahsanta Jambi \\ Email: fahmi.rohim.fr@gmail.com
}

\begin{abstract}
Religious expressions in rural areas is no longer a problem with the diversity it has. The social reality in Pangedaran Village is very concerning, various problems such as the education rate is very low, knowledge support activities are very minimal, even the drugs abuse is common in the village. the social setting accompanies the da'wah activities of the taklim, which demands that the recitation can fill Islamic knowledge and religious experience and the congregation's spiritual care. Thus, it is important to reveal the da'wah activities in the recitation in caring for the congregation's spirituality to pacify the human ego as spiritual beings. The purpose of this study is to explain the rituals, experiences of members in carrying out the routines of the taklim assembly to care for the spirituality of the congregation. Qualitative methods and descriptive analysis were used to complete and obtain relevant research results. Utilizing observation, in-depth interviews and documentation to support the data to answer the main questions of this research. The findings of this study, explained that the activities of the taklim assembly in caring for the congregation's spirituality were carried out by implementing dhikr, eradicating illiteracy, filling in religious
\end{abstract}

304 | TAJDID vol. 20, No. 2, Juli - Desember 2021 
knowledge, recitation rituals, reading prayers, it were done consistently.. it provide opportunities for social interaction and support the spiritual care of the congregation with social activities that form social capital so that they enter the gemeinschaft of mind group that has the same drive and motive, namely the spiritual instability of the congregation.

Keyword: majelis taklim; the spiritual congregation; preaching

\begin{abstract}
Abstrak
Melihat ekspresi keagamaan di pedesaan sudah tidak menjadi persoalan dengan keberagaman yang dimilikinya. Realitas sosial di Desa Pangedaran sangat memprihatinkan, berbagai persoalan seperti angka pendidikan sangat rendah, aktivitas pendukung pengetahuan sangat minim, bahkan maraknya narkoba sudah menjadi rahasia umum di Desa tersebut. Setting sosial demikian mengiringi aktivitas dakwah majelis taklim, yang menuntut pengajian dapat mengisi pengetahuan keislaman dan pengalaman keagamaan dan perawat ruhani jemaah. Dengan demikian penting untuk mengungkap aktivitas dakwah dalam pengajian tersebut dalam merawat ruhani jemaah dapat menentramkan ego manusia sebagai makhluk spiritual dan landasan aritkel ini. Tujuan penelitian ini untuk menjelaskan ritual, pengalaman anggota dalam menjalankan rutinitas majelis taklim untuk merawat kerohanian jemaah. Metode kualitatif dan menganalisis secara deskriptif digunakan untuk menyelesaikan dan memperoleh hasil penelitian yang relevan. Memanfaatkan observasi, wawancara mendalam dan dokumentasi dalam mendukung informasi atau data akurat untuk menjawab pertanyaan utama dari penelitian ini. Hasil dan diskusi pada temuan penelitian ini, menjelaskan bahwa aktivitas majelis taklim dalam merawat ruhani jemaah dilakukan dengan pelaksanaan zikir, pengentasan buta aksara, mengisi pengetahuan keagamaan, ritual-ritual pengajian, pembacaan do'a, amalanamalan dan selawat dilakukan secara konsisten. Rutinitas jemaah memberi peluang interaksi sosial dan mendukung perawatan ruhani jemaah dengan kegiatan sosial yang membentuk modal sosial sehingga mereka masuk ke dalam kelompok gemeinschaft of mind yang memiliki dorongan dan motif sama, yaitu ketidakstabilan spiritual atau ruhani jemaah.
\end{abstract}

Kata Kunci: dakwah; majelis taklim; ruhani jemaah

\title{
Pendahuluan
}

Eksistensi majelis taklim dan umat Islam adalah dua hal yang tidak terpisah. Karena keduanya saling berinteraksi, mengisi dan 
mempengaruhi. Secara umum majelis taklim berada di tengah masyarakat didukung oleh masyarakat, bahkan inisiatif dari umat Islam baik secara individu maupun komunitas. Sehingga pengetahuan yang diperoleh dari aktivitas majelis taklim dapat memberi perubahan sosial. ${ }^{1}$ Hal ini disebabkan potensi majelis taklim tidak begitu tergali secara mendalam, bahkan majelis taklim kerap dipandang taken for granted bagi masyarakat awam dan akademisi. Kondisi demikian memicu penelitian majelis taklim ibuibu ini tidak mungkin ditawar lagi. ${ }^{2}$

Secara umum majelis taklim dihadiri oleh kaum perempuan sehingga ia identik dengan pengajian ibu-ibu. ${ }^{3}$ Beberapa kelompok menganggap bahwa perempuan tidak memiliki kemampuan untuk mendalami kajian agama dan melibatkannya dalam membuat hukum. ${ }^{4}$ Hal demikian bertentangan dengan temuan Umdatul Hasanah yang menyebutkan beberapa tokoh majelis taklim mampu mendapatkan kepercayaan publik, tidak terbatas pada persoalan agama, tetapi meluas ke ruang publik di panggung nasional bahkan internasional. Ia menyadari bahwa saat ini keberadaan majelis taklim juga memiliki nilai tawar yang banyak ditunggu terkait sikap dan kewenangannya menyikapi realitas kehidupan umat Islam. ${ }^{5}$

Majelis taklim telah lama berkembang dan hadir dalam kehidupan masyarakat muslim sebagai media dakwah dan lembaga kependidikan yang diminati untuk memperoleh pengetahuan 7.

${ }^{1}$ Henda, Panduan Umum Majelis Ta'lim (Jawa Barat: Yayasan AMMA, 2010),

2 Khaerul Umam Noer, "Majelis Taklim Perempuan Dan Transformasi Otoritas Keagamaan Dalam Perspektif Feminist Anthropology" (Surabaya, 2009).

3 Umdatul Hasanah, Majelis Taklim Perempuan Dan Perubahan Sosial Pada Masyarakat Perkotaan (Magelang: PKBM 'Ngudi Ilmu', 2017), iv.

${ }^{4}$ Alimatul Qibtiyah, 'Pengakuan Ulama Dan Isu Perempuan Di Majlis Trajih Dan Tajdid Muhammadiyah', dalam Demokratisasi Fatwa, Diskursus, Teori Dan Praktik, ed. Syafiq Hasyim (Tangerang Selatan: International Center for Islam and Pluralism (ICIP), 2018), 193-211.

${ }^{5}$ Umdatul Hasanah, "Majelis Taklim and the Shifting of Religious Public Role in Urban Areas," Ilmu Dakwah: Academic Journal for Homiletic Studies, 13, no. 1 (2019): 97. 
keagamaan. ${ }^{6}$ Kehadiran majelis taklim bagi masyarakat dapat dinyatakan sebuah fenomena unik, karena lembaga ini memiliki akar dalam sejarah dan dakwah Rasulullah, selain itu lembaga ini tetap hidup di abad modern. ${ }^{7}$ Bahkan keberadaan majelis taklim dapat berfungsi sebagai alternasi pendidikan non formal bagi perempuan, sehingga ia terus diminati dalam memenuhi pengetahuan keagamaan dan sekaligus gerakan sosial keagamaan. ${ }^{8}$

Program Penelitian Pemberdayaan Perempuan dalam Konteks Muslim (WEMC), menyimpulkan bahwa majelis taklim tidak hanya memberikan manfaat untuk menimba ilmu agama. Melalui proses pembelajaran dua arah dan desain khusus materi terkait berbagai masalah nyata yang dihadapi perempuan, majelis taklim dapat mendorong perempuan untuk memberdayakan diri dan menantang otoritas publik dan pemuka agama. ${ }^{9}$ Melalui majelis taklim perlahan akhlak jemaah yang selalu hadir berubah lebih baik, namun terdapat sedikit anggota yang belum mengalami perubahan. ${ }^{10}$ Karena aktivitas yang dilakukan berbasis masyarakat dengan kekhasan nilai Islam dalam pelaksanaan majelis taklim yang berkelanjutan. Sehingga ia memberi kontribusi terhadap perempuan dalam berbagai bidang: pertama, dapat meningkatkan pengetahuan keagamaan, kedua, pengembangan keterampilan,

6 Givani Anisa Putri, Imron A. Hakim, dan Evy Ratna Kartika Wati, "Dinamika Kelompok Pada Majelis Taklim Jami'atul Muslimah Di Desa Mataram Kabupaten Musi Rawas," Journal of Non formal Education and Community Empowerment 3, no. 1 (2019): 44-51.

7 Asnil Aidah Ritonga dan Mahariah, "Majelis Taklim Sebagai Sebuah Lembaga Pendidikan," Al-Kaffah 2, no. 2 (2014): 143-76.

${ }^{8}$ Rumadani Sagala, "Peran Majelis Taklim Al-Hidayah Dalam Pendidikan Islam Dan Gerakan Sosial Keagamaan Di Propinsi Lampung," AL-MURABBI: Jurnal Studi Kependidikan Dan Keislaman 6, no. 1 (2019), 34.

${ }^{9}$ Dini Anitasari et al., "Perempuan Dan Majelis Taklim: Membicarakan Isu Privat Melalui Ruang Publik Agama Penulis :," April (2010): 3.

10 Mega Lestari Ningsih, "Urgensi Dakwah Dalam Pembinaan Akhlak Jamaah Di Majlis Taklim Al-Hidayah Desa Keranggan Kecamatan Sekernan Kabupaten Muaro Jambi” (Jambi, 2020). 
As'ad, Muhammad Rafii, Abdurahman Syayuthi, Fahmi Rohim

ketiga, mengentas buta aksara, keempat, menjadi tempat menggali pengetahuan agama berbasis masyarakat sepanjang hidup. ${ }^{11}$

Majelis taklim di Indonesia tersebar dan menyatu dengan masyarakat, hal ini menunjukkan peningkatan semangat keberagamaan umat Islam yang dibina melalui lembaga majelis taklim telah membawa arti penting dalam kehidupan. Lembaga pendidikan non formal tersebut telah berhasil membina umat dan dimanfaatkan untuk rekreasi ruhani, silaturrahmi antar ulama, guru, ustadz, kyai bersama umat. ${ }^{12}$ Rekreasi ruhani merupakan bagian dari ritual dalam diri manusia untuk mencapai keruhanian atau rasa spiritual yang dapat ditumbuhkan melalui proses yang berkelanjutan.

Artikel ini tidak dapat melepaskan bahwa bahwa konsep ruhani merupakan hal fitrah dalam diri manusia, sehingga ia memungkinkan untuk hilang dan atau tetap kokoh dalam batin setiap individu. Rasa ruhani menjadi simbol atau identitas bahwa manusia merupakan makhluk spiritual yang menduduki fisik jasmani. Oleh karena itu, rasa ruhani dapat terjadi oleh orang yang berbeda-beda. Dengan demikian kesadaran spiritual melalui rutinitas seperti zikir dan aktivitas keagamaan lainnya, dapat menetramkan ego manusia dalam menyikapi realitas. ${ }^{13}$

Zikir, adalah alah satu aktivitas majelis taklim yang biasa disebut oleh ustadzah dan jemaah dengan "syair pengajian". Majelis taklim ini berada di Desa Pangedaran Kecamatan Pauh, Kabupaten Sarolangun, Provinsi Jambi. Pengajian tersebut dilakukan secara konsisten untuk mengajar dan membimbing kaum muslimah baik dalam ibadah, pengetahuan keagamaan dan

11 Helmawati, "Meningkatkan Pendidikan Perempuan Indonesia Melalui Optimalisasi Majelis Ta'lim," INS ANCITA: Journal of Islamic Studies in Indonesia and Southeast Asia, 3, no. 1 (2018): 65-88.

12 Hanny Fitriyah, Darmi AR, dan Rakhmad Zailani Kiki, Manajemen \& Silabus Majelis Taklim (Jakarta Utara: Pusat Pengkajian dan Pengembangan Islam Jakarta (Jakarta Islamic Centre), 2012), 10.

13 M.Iqbal Irham, Rasa Rubani: Spiritualitas Di Abad Modern (Bandung: Citapustaka Media Perintis, 2012).

308 | TAJDID vol. 20, No. 2, Juli - Desember 2021 
berbagai ritual agama lainnya. Pertanyaan utama dalam penelitian ini yaitu bagaimana aktivitas dakwah di majelis taklim dalam perawatan ruhani jemaah atau rasa spiritualitas pada majelis taklim di Desa Pangedaran. Fokus artikel ini ialah meliputi aktivitas majelis taklim dan rutinitas zikir, sehingga keberadaan pengajian tersebut terlibat dalam merawat ruhani jemaah yang dapat menambah kekokohan rasa spiritual jemaah atau bahkan sebaliknya.

Di Kementerian Agama Provinsi Jambi, berjumlah ratusan bahkan ribuan majelis taklim yang terdata pada periode tertentu, seperti 306 MT (Kabupaten Tanjung Jabung Timur, 2018), 86 MT (Kota Sungai Penuh, 2019), dan 439 MT (Kabupaten Merangin, 2019). Di Jambi majelis taklim dalam aktivitas politik Pilkada tahun 2020. Syafril Nursal yang merupakan pasangan calon Gubernur Jambi yaitu Fachrori-Syafril mengunjungi pengajian majelis taklim yang sedang berlangsung, pada saat itu Syafril mengakui bahwa majelis taklim dapat bersosialisasi dan berdiskusi antara satu orang dengan yang lain. ${ }^{14} \mathrm{Hal}$ di atas sangat berpeluang secara politis, sebagaimana diperlihatkan oleh sebuah studi yang menjelaskan bahwa majelis taklim menjadi media untuk berinteraksi dengan politisi dan menarik jemaah dengan menggunakan identitas agama, ritual dan kekuatan posisi mereka untuk menggalang dukungan politik. $^{15}$

Di Sarolangun majelis taklim mendapat bimbingan dari Kepala Kantor Urusan Agama (KUA) Kec. Pauh, di Desa Karang Mendapo yang dihadiri kurang lebih 50 anggota majelis taklim. ${ }^{16}$ Majelis Taklim Nurul Yakin Desa Pauh telah diteliti oleh Rohman mengenai strategi dai dalam menyampaikan nilai keislaman pada

14 SM, "Emak-Emak Majelis Taklim Kota Jambi Berikan Dukungan Ke Fachrori-Syafril," Jamberita.Com, 2020, https://jamberita.com.

${ }^{15}$ Nisaul Fadillah, "Female Brokers: Mobilising Voters within Indonesia's Majelis Taklim Network," Global Media Journal Australian, 14, no. 1 (2020): 12.

16 akb, "KUA Kec Pauh Memberikan Bimbingan Majelis Taklim," Kantor Wilayah Kementerian Agama Provinsi Jambi, 2013, https://jambi.kemenag.go.id. 
Majelis taklim dilakukan. ${ }^{17}$ Sedangkan di Desa Pangedaran Kec. Pauh, majelis taklim belum ditemukan penelitian sejenis dari aspek apapun. Di Pangedaran aktivitas majelis taklim rutin melakukan zikir dan selawat dalam rangka merawat ruhani jemaah. Menurut Iqbal rasa ruhani manusia dapat dipraktikkan dengan melakukan zikir, ia merupakan metode yang harus dilakukan secara berkelanjutan karena pada metode ini akan dapat mendeteksi ruhani dalam diri manusia. ${ }^{18}$ Oleh karena itu, posisi artikel ini bertujuan mendeskripsikan aktivitas majelis taklim seperti zikir, selawat, bacaan sejumlah amalan dan sebagainya yang berkontribusi pada perawatan ruhani jemaah.

Artikel ini menggunakan metode kualitatif. Penelitian lapangan untuk meneliti objek alamiah dalam aktivitas majelis taklim, peneliti menjadi instrumen kunci pada metode tersebut. Penelitian lapangan berupaya meneliti, menyelidiki, menemukan, menggambarkan, mempelajari, memahami dan menjelaskan seseorang atau sekelompok orang pada suatu komunitas yang berinteraksi. Peneliti menggunakan teknik penelitian dalam mempelajari masyarakat mereka sendiri. ${ }^{19}$ Pengumpulan data dilakukan dengan observasi, wawancara mendalam dilakukan pada sejumlah partisipan: Ustadzah Ama Kalsum; Ketua majelis taklim; dan beberapa jemaah; dokumentasi; foto maupun peta untuk memperoleh informasi dan data akurat dalam menjawab pertanyaan penelitian yang dapat dipertanggungjawabkan. Wawancara lapangan dihasilkan dari interaksi peneliti dan anggota majelis taklim, ustadzah, dan masyarakat. Data tersebut dianalisis terkait aktivitas dan konsistensi majelis taklim dalam merawat aspek ruhani jemaah yang dilaksanakan untuk mendidik masyarakat

17 Fathur Rohman, "Strategi Da'i Dalam Menyampaikan Nilai-Nilai Keislaman (Studi Majelis Ta'lim Nurul Yakin Desa Pauh Kecamatan Pauh Kabupaten Sarolangun Jambi)" (Jambi, 2018).

${ }_{18}$ M.Iqbal Irham, Rasa Ruhani: Spiritualitas Di Abad Modern, 136.

${ }^{19}$ W. Lawrence Neuman, Social Research Methods: Qualitative and Quantitative Approaches, 7th ed. (Boston: Pearson Education, 2011), 462-463. 
muslimah baik dalam bidang ibadah maupun muamalah di Desa Pangedaran Kecamatan Pauh Kabupaten Sarolangun.

\section{Pembahasan}

Majelis taklim di Desa Pangedaran merupakan salah satu wilayah di Kec. Pauh Kabupaten Sarolangun Provinsi Jambi. Majelis taklim ini rutin dilakukan di hari Jumat di Masjid AtTaubah RT.02 dimulai dari jam 14.00 sampai 16.00 WIB. Majelis taklim ini mengalami berbagai perubahan respon masyarakat maupun anggota majelis taklim tersebut. Semangat anggota komunitas dalam aktivitas pengajian telah terjadi pergeseran dan naik turun kehadiran jemaah setiap pertemuan.

Suatu ketika pengajian yang dilaksanakan dengan jemaah yang begitu besar, namun pada waktu lain pengajian hanya dihadiri oleh beberapa orang. Hal demikian tidak menjadi hambatan dan penghalang ustadzah untuk tetap menjaga spirit dakwah melalui majelis taklim. Pada suatu ketika sempat terjadi bahwa ustadzah yang menunggu kedatangan anggota pengajian, semangat untuk menyebarkan pengetahuan keagamaan dan memperbaiki perilaku dan moral masyarakat menjadi motif bagi pengajar untuk terus konsisten menyebarkan ajaran Islam pada satu kelompok maupun individu.

Masyarakat sekitar sesungguhnya mengetahui keberadaan majelis taklim tersebut dan penyelenggaraannya di Masjid AtTaubah, namun semangat beragama dan kebutuhan akan nasehatnasehat agama masih kurang bagi warga sekitar. Padahal dari desa tetangga yaitu Desa Pauh, terdapat beberapa orang yang mengikuti pengajian yang diselenggarakan di Masjid tersebut. Namun, dikarenakan masyarakat desa ini tidak begitu antusias untuk mengisi kekurangan pengetahuan agama dan kekeringan spiritual sehingga majelis taklim tersebut tidak dapat mereka ikuti bersama anggota pengajian lainnya. 
Generasi muda di Desa Pangedaran tidak mendapat pendidikan keagamaan yang memadai, sedangkan orang tua atau masyarakat luas tidak begitu minat dengan pengajian-pengajian keagamaan. Bahkan tidak dapat dihindari, aktivitas anak muda Desa ini diiringi penyebaran narkoba atau obat terlarang lainnya yang marak dan mudah diakses oleh masyarakat. Namun, dalam kehidupan realitas sosial demikian, pengajian ibu-ibu bertahuntahun bahkan puluhan tahun terus berlanjut, tidak khawatir atas pujian dan cacian masyarakat sekitar, kaum ibu-ibu dan orangorang berumur tetap konsisten mempelajari ilmu keislaman dan mengasah serta merawat ruhani jemaah secara terus-menerus.

Masjid menjadi pusat kegiatan keagamaan dan aktivitas sosial yang dapat menyadarkan anggota jemaah bahwa agama terlibat dalam menyelesaikan persoalan masyarakat, pengetahuan keagamaan, dan kehidupan sosial. ${ }^{20}$ Majelis taklim di Desa Pangedaran melaksanakan pengajian di masjid sebagai rumah pemersatu umat, pusat pendidikan masyarakat, dan medan silaturahmi umat Islam.

\section{Majelis Taklim: Konsistensi di Jalan Dakwah}

Majelis taklim di Desa Pangedaran ini dibentuk untuk menjadi wadah dalam memenuhi kebutuhan masyarakat dalam mempelajari Islam. Ama Kalsum menyatakan bahwa majelis taklim di Desa Pangedaran telah dilakukan sejak tahun 1983. Namun pengajian tersebut rutin dilakukan di tahun $1987 .{ }^{21}$ Tujuan pelaksanaan pengajian tersebut semula adalah mengirim doa kepada ruh yang telah mendahulu mereka, membaca al-Fatihah, Surat al-Ikhlas, al-Falaq dan al-Nas, agar para jemaah dan orang tua yang mengikuti majelis tersebut selalu mengingat kematian.

${ }^{20}$ Mukhibat, "Rekonstruksi Spirit Harmoni Berbasis Masjid (Studi Kasus KPM Tematik Posdaya Di Kecamatan Pulung Kabupaten Ponorogo)," dalam Memahami Realitas Sosial Keagamaan, ed. Raudatul Ulum (Puslitbang Kehidupan Keagamaan Badan Litbang dan Diklat Kementerian Agama RI, 2015), 185.

${ }^{21}$ Wawancara, Ustazdah Ama Kalsum, 16 Oktober 2020. 
Sejak 1987 hingga sekarang pengajian atau majelis taklim tersebut dilakukan pada hari Jumat sore. Jemaah pengajian atau majelis taklim tidak ada batasan usia, baik muda maupun tua, yang terpenting adalah bahwa seseorang tersebut memiliki keinginan untuk mempelajari ilmu agama yang diajarkan di majlis taklim tersebut. ${ }^{22}$ Majelis taklim telah memberi manfaat besar, karena mampu menambah wawasan bagi jemaah dan komunitas muslim. Dalam kehidupan nyata majelis taklim menjadi tempat pembelajaran keagamaan yang sangat fleksibel, tidak tertutup bagi usia tertentu, lapisan masyarakat, maupun jenis kelamin. Sehingga majelis taklim menjadi alternatif bagi pemenuhan kebutuhan pengetahuan umat Islam bagi kalangan tertentu. ${ }^{23}$

Sejak awal hingga sekarang pengajian ini diajarkan oleh Ustazah Ama Kalsum. Majelis taklim ini diketuai oleh Nyai Emilia. Anggota majelis taklim pada awalnya berjumlah 15 orang hingga berkembang dan bertambah peminatnya sampai saat ini. Permintaan masyarakat setempat dan khususnya jemaah majelis taklim untuk memperbaiki ibadah, puasa, salat dan ibadah lainnya. ${ }^{24}$ Harapan masyarakat sesungguhnya adalah realitas sosial yang tidak mungkin diabaikan dalam menjawab kekosongan pengetahuan dan semangat beragama umat muslim. Hal ini pula yang menuntut peran penting majelis taklim untuk meningkatkan pengetahuan, pemahaman, serta pengamalan Islam bagi masyarakat muslim dewasa. ${ }^{25}$ Dengan demikian majelis taklim menjadi media

22 Wawancara, Ustazdah Ama Kalsum.

23 Aspari Ismail, Penguatan Pendidikan Islam Informal Dan Non Formal, ed. Moh. Haitami (Pontianak: Bulan Sabit Press, 2016), 7.

${ }^{24}$ Wawancara, Ketua Majels Taklim, 17 Oktober 2020.

25 Suhirman, Rini Fitria, dan Fathan Awwalur Rayyan, "Dakwah Subuh Dan Filantropi Islam: Praktik Terbaik Pembelajaran Dakwah Di Era Millenial," Jurnal Ilmiah Syiar 20, no. 1 (2020): 65. 
dakwah yang berorientasi pada memasyarakatkan Islam, seperti dilaksanakan di musholla, masjid dan tempat lainnya. ${ }^{26}$

Dakwah dalam kerangka strategi kebudayaan meliputi semua wilayah kehidupan manusia yang bermuara pada peradaban dan perubahan dimensi masyarakat untuk mensejahterahkan kehidupan duniawi dan ukhrawi. ${ }^{27}$ Karena pendekatan dakwah dapat memasuki kehidupan manusia yang kompleks. Sehingga dakwah berperan dalam pemulihan keseimbangan, mengarah pada pembebasan, serta persaingan terhadap budaya lain. ${ }^{28}$ Terlihat dalam pengajian ini tidak ada aktivitas arisan, baju seragam, ${ }^{29}$ hal ini tidak dianjurkan oleh ustazah tersebut, jadi dalam pengajian memakai pakaian apa adanya, tidak perlu harus mengeluarkan biaya untuk membuat seragam atau membeli makanan. Demikian merupakan aktivitas dan praktik dalam merawat ruhani jemaah dengan menjauhkan jemaah dari ketergantungan materi dan menghindarkan dari perbuatan duniawi yang dapat merusak kesadaran spiritual manusia. Hal ini dapat menunjukkan bahwa ruhani jemaah secara sistematis dirancang oleh ustadzah untuk menafikan beban materi terhadap anggota majelis taklim. Berbeda dengan rutinitas pengajian di kalangan masyarakat urban yang mana majelis taklim menjadi wadah hijrah; fashion, simbol-simbol keagamaan menjadi praktik konsumtif bagi majelis taklim kelas menengah. Dwi menyimpulkan bahwa hijrah pada komunitas majelis taklim ini adalah konversi dari non-Salafi menjadi gerakan

26 Ahmad Darlis, "Hakikat Pendidikan Islam: Telaah Antara Hubungan Pendidikan Informal, Non Formal Dan Formal," Jurnal Tarbiyah XXIV, no. 1 (2017): 93-94.

27 Waryono Abdul Ghafur, "Dakwah Dan Interaksi Interkultural," dalam Dakwah Humanis, ed. Muhammad Habibi Siregar and Joko Susanto (Bandung: Citapustaka Media, 2014), 70.

28 Yasril Yazid dan Nur Alhidayatillah, Dakwah Dan Perubahan Sosial (Jakarta: PT RajaGrafindo Persada, 2017), 20-21.

${ }^{29}$ Wawancara, Ustazdah Ama Kalsum. 
Salafi, sehingga konsekunsinya kehidupan keagamaan di masyarakat kota telah terjadi pengaburan realitas fisik. ${ }^{30}$

Hal ini mempermudah jemaah dalam mengikuti pengajian, sehingga tidak terikat dan memberatkan jemaah dengan membawa makanan, honor, ataupun yang lain sebagaimana dakwah atau pengajian-pengajian di sebagian kota saat ini. Honorarium menjadi persoalan jika dikaitkan dengan dakwah. Sebagian tidak membenarkan jika aktivitas dakwah dihubungkan dengan gaji. Namun pandangan lain membolehkan pemberian honor, namun hal tersebut tidak mengurangi kebersihan hati, istiqamah, serta kesungguhan dai dalam berdakwah. Idealnya, lembaga tertentu atau pemerintah yang bertanggung jawab terhadap imbalan bagi ustadz, dai, guru, maupun imam yang memiliki perhatian penuh dalam mendakwahkan Islam. ${ }^{31}$

Kemudahan tersebut terlihat bagaimana para jemaah tetap konsisten mengulang-ngulang kajian sebelumnya bila ustadzah yang mengisi pengajian tidak hadir, para jemaah tetap melangsungkan pengajian tersebut, membaca syair, doa, dan amalan-amalan yang tertulis dalam salinan syair. ${ }^{32}$ Di sini terlihat bahwa konsistensi jemaah dalam menyelenggarakan pengajian adalah hasil dari pemeliharaan spirit jemaah yang telah berlangsung bertahun-tahun. Sehingga anggota majelis taklim menjadikan kegiatan pengajian tersebut sebagai aktivitas wajib, rutin dilakukan setiap hari Jumat, hadir ataupun tidak guru yang mengajari mereka, pengajian tetap berlangsung hingga mereka dapat mengembangkan kualitasnya. Demikian interaksi anggota jemaah dalam bekerjasama dalam memadukan peran sehingga kemampuan dan kebutuhan

30 Dwi Retnani Srinarwati, Pinky Saptandari Endang Pratiwi, dan Diah Ariani Arimbi, "Simulacra in Women's Majelis Taklim Based on Jean Baudrillard's Perspective," JURNAL STUDI KOMUNIKASI 4, no. 3 (2020): 632.

31 Muchlis M. Hanafi, ed., Etika Berkeluarga, Bermasyarakat, Dan Berpolitik (Tafsir Al-Qur'an Tematik) (Jakarta: Lajnah Pentashihan Mushaf Al-Qur'an, 2009), 454.

32 Wawancara, Ketua Majels Taklim. 
spiritual mereka dapat dipenuhi. Dalam majelis taklim terlihat interaksi sosial bekerja secara alamiah, tidak ada aturan yang mengikat, saling menaklukkan atau mendominasi antara satu orang dengan yang lain.

Majelis taklim yang memuat syair-syair Islam menjadi wadah dakwah berkelanjutan yang memuat tema dari aspek akidah, ibadah, dan kematian. Demikian juga aktivitas majelis taklim di Desa ini seperti menjenguk jemaah yang tertimpa musibah, sakit, meninggal, syukuran, dan yasinan. ${ }^{33}$ Setelah pengetahuan tentang keagamaan diperoleh jemaah pengajian berupaya melakukan amal sosial dalam rangka mengamalkan ajaran Islam dan tetap menjalankan misi dakwah agar tetap menjaga ajaran agama di tengah-tengah masyarakat. Sehingga kegiatan demikian dapat mengembangkan kualitas jemaah secara berkelanjutan. ${ }^{34}$

Akidah atau keimanan adalah hal utama yang ditekankan untuk ditanam kepada umat manusia di masa awal dakwah Nabi dijalankan yaitu periode Makkah. Berbeda dakwah Nabi di Madinah yang memberi penekanan pada aspek terapan syariat Islam, penataan kehiduan manusia, dan pembangunan ekonomi umat sebagai dasar dalam bernegara dan berbangsa. ${ }^{35}$ Demikian penting akidah sebagai bahasan di dalam aktivitas dakwah umat Islam hari ini. Tidak dapat dipungkiri bahwa keimanan bukanlah sesuatu yang mudah untuk diletakkan porsinya dalam hidup manusia.

Majelis taklim kemudian menjadi suatu agama vernakular, akrab dengan masyarakat, merakyat, demokratis, egaliter yang mengisi kekurangan semangat religiusitas sosial, terkhusus ibu-ibu

${ }_{33}$ Wawancara, Ustazdah Ama Kalsum.

34 Muhammad Qadaruddin, A.Nurkidam, dan Firman, "Peran Dakwah Masjid Dalam Peningkatan Kualitas Hidup Masyarakat," Ilmu Dakwah: Academic Journal for Homiletic Studies 10, no. 2 (2016): 237.

${ }^{35}$ Sahdin Hsb, Politik. Arabisasi Dan Dakwah: Refleksi Perkembangan Dakwah Era Umaiyah Dan Upaya Kontekstualisasi Dakwah Kontemporer Di Indonesia (Medan: Perdana Publishing, 2019), 111. 
yang butuh terhadap agama sebagai landasan pendidikan dalam keluarganya. ${ }^{36}$ Seorang ustadzah menjadi agen dalam membina, mengajar serta menyadarkan jemaah dengan komunikasi persuasif. ${ }^{37}$ Pendekatan ini menghadirkan pola komunikasi kultural yang tidak membiarkan pemisah atau jarak antara pengajar dengan jemaah, sehingga pengajian dapat dilaksanakan secara egaliter.

Misi merawat ruhani kaum muslimah diselipkan dalam majelis taklim tersebut sebagai upaya menangkal jemaah dari berbagai tantangan dakwah di era milenial. Konsistensi anggota pengajian setiap minggu merupakan tanggapan kultural terhadap berbagai aktivitas dakwah di era media online yang mengakibatkan masjid absen dari aktivitas dakwah dan menjamur atau viralnya ceramah ustadz populer di youtube maupun media sosial lainnya. ${ }^{38}$ Pengajian tidak dapat berjalan terus-menerus jika ustadzah tidak memiliki kecerdasan komunikasi dan interaksi dengan masyarakat yang memiliki ragam karakter. Komunikasi menjadi suatu determinan ketika berinteraksi dengan berbagai lawan bicara, Islam telah memberi perhatian dan meletakkan prinsip dasar dalam berkomunikasi, yaitu perkataan yang benar, layak, lembut, baik, jelas dan fasih. ${ }^{39}$

Pembahasan tentang kematian, mendoakan arwah terdahulu, serta menjenguk orang yang meninggal adalah aktivitas spiritual dalam meningkatkan kesadaran atas kefanaan manusia dan keabadian Tuhan Maha Pencipta dan Maha Hidup. Sehingga dengan materi tersebut jemaah dapat menyadari keberadaannya di

${ }^{36}$ Muhammad Iskandar, Azyumardi Azra, and Muhammad Hisyam, Sejarah Kebudayaan Islam Indonesia Jilid 3 Jakarta: Direktorat Sejarah dan Nilai Budaya, Direktorat Jenderal Kebudayaan, Kementerian Pendidikan dan Kebudayaan, 2015), 415.

${ }^{37}$ Bustanol Arifin, "Strategi Komunikasi Dakwah Da'i Hidayatullah Dalam Membina Masyarakat Pedesaan," Communicatus: Jurnal Ilmu Komunikasi 2, no. 2 (2018): 159.

38 Suhirman, Fitria, dan Fathan Awwalur Rayyan, "Dakwah Subuh Dan Filantropi Islam: Praktik Terbaik Pembelajaran Dakwah Di Era Millenial,” 63.

39 Mubarok dan Made Dwi Andjani, Komunikasi Antarpribadi Dalam Masyarakat Majemuk. (Jakarta Timur: Dapur Buku, 2014), 8. 
dunia ini, asal-asul manusia, hakikat hidup di dunia dan tujuan akhir kehidupan manusia. Dalam studi tasawuf, manusia sebagai seorang ciptaan yang lemah ia harus sadar atas tugas serta kewajibannya sebagai hamba dan tanggung jawabnya di bumi. ${ }^{40}$

Hal ini bukan berarti mengabaikan aktivitas sosial sebagaimana kegiatan masyarakat pada umumnya. Menjenguk orang sakit, masyarakat tertimpa musibah, atau yasinan di rumah warga merupakan kegiatan majelis taklim yang cukup memperhatikan kehidupan nyata dimana pengetahuan, pemahaman, dan amalan yang diperbuat sebanyak-banyaknya tidak akan memberi manfaat kepada umat Islam jika tidak disosialisasikan secara kultural atau dengan dakwah bi al-hal. Selain itu, interaksi sosial yang dilakukan oleh anggota majelis taklim dan ustazdah tersebut adalah upaya membuat ikatan, memperkuat persatuan dan memperkokoh persaudaraan sesama umat Islam.

Majelis taklim kemudian menjalankan fungsi dan memasukkan makna dalam kegiatan pengajian, ${ }^{41}$ seperti fungsi dan makna religi; sosial budaya; apresiatif; reflektif dan kontemplatif baik yang berkaitan dengan syair pengajian di masjid maupun pertemuan di rumah ibu-ibu ketika yasinan. Keseluruhan makna dalam majelis taklim ini adalah bagian terpenting yang harus diungkapkan dan dilestarikan. Sehingga jemaah merasakan bagaimana persaudaraan sesama umat Islam terawat di satu sisi, dan aspek spiritual dan keruhanian anggota pengajian dapat terasah. Jemaah majelis taklim bila dapat bekerja dengan baik, memungkinkan lembaga pendidikan non formal ini disebut sebagai organisasi dakwah atau organisasi sosial keagamaan. ${ }^{42} \mathrm{Hal}$ ini terlihat ada usaha untuk melembagakan majelis taklim menjadi 104.

40 S. Hamdani, “Tasawuf Sebagai Bahan Terbaik Dakwah” (Jakarta, 2006),

41 Ni Luh Nyoman Seri Malini, Analisis Wacana: Wacana Dakwah Di Kampung Muslim Bali (Denpasar-Bali: Cakra Press, 2016), 88.

42 Mujahidin, "Urgensi Majelis Taklim Sebagai Lembaga Dakwah Di Masyarakat," Jurnal Alhadharah 17, no. 33 (2018): 5. 
sebuah rumah bersama untuk melakukan kerja-kerja keagamaan maupun sosial.

\section{Mengentas Buta Aksara Jalan Merawat Ruhani Jemaah}

Tujuan syair pengajian ini dilakukan untuk beribadah, mengajarkan pengetahuan agama kepada masyarakat khususnya kaum muslimah di Desa Pangedaran. Secara umum tujuan pengajian ini diselenggarakan untuk mengembangkan ajaran agama. Sebagaimana dinyatakan oleh Ustadzah Ama Kalsum:

Memperkembangkan apo namo ko perjuangan agama, jangan agama tu putus kan. Mengembangkan pengajian tu pengajaran agama. Mengajar baco huruf Arab. ${ }^{43}$

Sebelum pengajian dimulai, terlebih dahulu belajar membaca huruf Arab, selawat, penyelenggaraan jenazah. Dimulai dengan mempelajari sembahyang orang mati, belajar ngaji. ${ }^{44}$ Karena ketika pertama kali pengajian ini diselenggarakan para jemaah terkhusus orang-orang tua di masa itu tidak bisa membaca huruf Arab, jadi membaca yasin hanya melihat huruf latinnya. ${ }^{45}$ Namun setelah keberlangsungan majelis taklim yang kian lama, para anggota majelis sudah mampu membaca huruf Arab, ayat-ayat pendek dan membaca syair-syair yang bertuliskan huruf Arab. Secara alamiah majelis tersebut ikut berperan membina pengetahuan keislaman jemaah pengajian. ${ }^{46}$

Keprihatinan tersebut menjadi alasan pokok atas kehadiran pengajian di Desa Pangedaran, Sehingga pertama kali yang ditekuni adalah belajar huruf Arab, mengaji. Sehingga target awalnya adalah pengentasan buta aksara Arab di Desa ini, jika sudah mampu, kemudian dilanjutkan mempelajari salat jenazah, mandi jenazah,

43 Wawancara, Ustadzah Ama Kalsum.

44 Wawancara, Naimah, 20 Oktober 2020.

45 Wawancara, Ustadzah Ama Kalsum.

46 Firman Nugraha, "Majelis Taklim Sebagai Basis Pemberdayaan Umat," Jurnal Diklat Keagamaan XII, no. 33 (2018): 108. 
kemudian mempelajari syair-syair perlembar setiap pengajian digelar, membaca syair-syair yang telah disusun dan dibagikan kepada jemaah, hingga saat ini para jemaah sudah mahir dan bahkan hafal syair-syair yang dilantunkan setiap kali pengajian dilakukan. ${ }^{47}$

Pengetahuan adalah hal penting dalam menopang peningkatan keruhanian manusia sebagai karunai Tuhan, berbekal kemampuan seorang hamba dapat sadar akan kehidupannya berlandaskan pada kesadaran adanya Allah dan pengarah hidup seseorang. Ruh Tuhan yang ditiupkan kepada manusia serta perlengkapan seperti panca indera lahir maupun batin merupakan tanda bahwa manusia adalah makhluk keruhanian. ${ }^{48}$ Majelis taklim berkontribusi bagi pengembangan pengetahuan jemaah, hal demikian tampak pada perubahan sikap dan kesungguhan anggota pengajian untuk terus mempelajari dan mendalami pemahaman keislaman. ${ }^{49}$

Dakwah pada ruang substansif merupakan aktivitas rekayasa serta rekadaya dalam mengubah berbagai bentuk persembangan terhadap selain Allah menjadi tauhid, dari kehidupan timpang menuju hidup yang lempang, dipenuhi dengan nilai Islam yang dapat menggerakkan batin dan lahir. ${ }^{50}$ Majelis taklim selain lembaga dakwah ia juga berfungsi sebagai pendidikan non formal. Kekuatan yang dimiliki oleh Majelis taklim ialah fleksibelitas, sehingga ia tetap bertahan dan paling dekat dengan kehidupan umat. Bahkan ia menjadi media komunikasi interaktif antara umat

47 Wawancara, Kulsum, 20 Oktober 2020.

48 Muchlis M. Hanafi, ed., Spiritualitas Dan Akblak (Tafsir Al-Qur'an Tematik) (Jakarta Timur: Lajnah Pentashihan Mushaf Al-Qur'an, 2012), 118.

49 Asep Shodiqin Saeful Lukman, Yusuf Zaenal Abidin, "Peranan Majelis Taklim Dalam Meningkatkan Pemahaman Keagamaan Masyarakat," Tabligh: Jurnal Komunikasi Dan Penyiaran Islam 4, no. 1 (2019): 65.

50 Agus Ahmad Safei, Sosiologi Dakwah: Rekonsepsi, Revitalisasi, Dan Inovasi (Yogyajarta: Deepublish, 2016), 62. 
dan mu'alim atau antara jemaah yang tidak terbatas. ${ }^{51}$ Majelis taklim menjadi aktivitas pendidikan keagamaan yang dapat ditempuh oleh berbagai pihak dengan kelenturan kegiatan yang dimilikinya. Sehingga ia tidak begitu formal dan tidak memiliki jenjang dalam melaksanakan kegiatan majelis taklim. Sebagaimana tertulis dalam Undang-Undang No 20 Tahun 2003 tentang Sistem Pendidikan Nasional pada Pasal 1 Ayat 11, 12, dan 13. Berikut gambaran isi Undang-Undang tersebut:

Tabel I: Pendidikan Diniyah/Keagamaan

\begin{tabular}{|l|l|l|}
\hline No & \multicolumn{1}{|c|}{ Jenis } & \multicolumn{1}{c|}{ Keterangan } \\
\hline 1 & Formal & $\begin{array}{l}\text { Diniyah Athfal } \\
\text { Diniyah Ula } \\
\text { Diniyah Wustha } \\
\text { Diniyah Ulya } \\
\text { Ma'had 'Aly }\end{array}$ \\
\hline 2 & Nonformal berjenjang & $\begin{array}{l}\text { Diniyah Takmiliyah Awaliyah } \\
\text { Diniyah Takmiliyah Wustha } \\
\text { Diniyah Takmiliyah Ulya } \\
\text { Diniyah Takmiliyah 'Aly }\end{array}$ \\
\hline 3 & Nonformal tak berjenjang & $\begin{array}{l}\text { Pengajian Kitab } \\
\text { Majelis Taklim } \\
\text { Pendidikan al-Qur'an } \\
\text { Bentuk lain sejenis }\end{array}$ \\
\hline 4 & Informal & Keluarga dan Lingkungan \\
\hline
\end{tabular}

Tabel di atas adalah klasifikasi pendidikan keagamaan sebagaimana diatur dalam perundang-undangan. Majelis taklim masuk pada jenis pendidikan keagamaan non formal berjenjang. Hal ini membuat majelis taklim lebih leluasa untuk beraktivitas tanpa harus terikat oleh mekanisme struktual sebagaimana terjadi pada lembaga formal. Kantor Wilayah Kementerian Agama Provinsi Jambi memberi perhatian signifikan atas aktivitas majelis

51 Asep Ahmad Fathurrohman, Ilmu Pendidikan Islam Sebuah Pengantar (Dengan Pendekatan Teologis Dan Filosofis) (Bandung: Pustaka Al-Kasyaf, 2013), 141. 
taklim di Provinsi Jambi, ${ }^{52}$ dengan memberi Bantuan Operasional Majelis Taklim di Tahun 2020 adalah upaya untuk memaksimalkan peran majelis taklim di Jambi dalam melaksanakan pengajaran Islam yang dikelola oleh lapisan masyarakat. Hal ini memperlihatkan demikian penting pengajaran, pendidikan dan memberi pemahaman kepada masyarakat yang berkaitan dengan pengetahuan keagamaan Islam.

Kesadaran terhadap ketidaktahuan masyarakat dan identifikasi ustadzah terhadap jemaahnya adalah modal untuk mengambil langkah berikutnya. Pembelajaran keagamaan yang diberikan sesungguhnya adalah panggilan moral dan tugas dakwah atas kenyataan masyarakat Desa Pangedaran yang demikian memprihatinkan. Meskipun sesungguhnya dakwah seharusnya dipikul oleh seluruh umat manusia. Namun dikarenakan keterbatasan pengetahuan sehingga tugas tersebut hanya diemban oleh sebagian orang seperti; ulama, ustadz/ustadzah, guru agama dan lain sebagainya. Maka seorang yang berpengetahuan harus mengambil tugas tersebut, karena bagaimana mungkin suatu masyarakat dapat mengalami kemajuan jika tidak berpengetahuan, atau meningkatkan keimanan jika tidak didukung dengan pengetahuan keagamaan, tentu sangat memprihatinkan jika anggota masyarakat diam di tengah kebodohannya, keselamatan pun tidak akan tercapai oleh umat Islam. ${ }^{53}$ Menurut perspektif Islam tanggung jawab seorang muslim terhadap masyarakat tidak terbatas, bahkan pada konteks tertentu diperintahkan untuk mendahulukan kepentingan orang lain daripada diri sendiri. ${ }^{54}$

Diantara tema-tema pengajian yang dipelajari yaitu; mandi wajib khususnya bagi perempuan, makanan yang halal, makanan

52 "Pengumuman Tentang Bantuan Operasional Majelis Taklim," Kantor Wilayah Kementerian Agama Provinsi Jambi, 2020, http://jambi.kemenag.go.id.

53 Rosyidi, Dakwah Sufistik Kang Jalal: Menentramkan Jiwa, Mencerabkan Pikiran (Jakarta: Paramadina, 2004), 2.

54 Syamsuddin, Pengantar Sosiologi Dakwah Edisi Pertama (Jakarta: Kencana, 2016), 44. 
yang baik untuk keluarga, karena seorang wanita atau istri harus mengetahui bahwa makan yang disajikan kepada keluarganya bersih dari keragu-raguan, tidak syubhat sumbernya dan berbagai pembahasan lainnya. ${ }^{55}$ Kesadaran terhadap beban moral dalam mewujudkan masyarakat religius ikut menentukan dalam aktivitas majelis taklim. ${ }^{56}$ Karena demikian muatan pembahasan pada pengajian tersebut meliputi aspek muamalah dan spiritualitas umat Islam yang dapat menambah binaan bagi keluarga secara signifikan. Sebagaimana terlihat hubungan positif dan memiliki signikansi antara majelis taklim dan pembinaan terhadap keluarga dalam mewujudkan rumah tangga yang sakinah. ${ }^{57}$ Karena kecerdasan ruhani seseorang dapat diwujudkan apabila dapat memadukan intelektualitas dan emosional dalam memaknai kehidupan agar dipenuhi berkah oleh Tuhan al-Haqq. ${ }^{58}$

Demikian halnya pengajian ini beranggotakan ibu-ibu tema terkait keluarga, membina keluarga, kependidikan Islam dan menjalankan dakwah dapat berkembang dan tumbuh subur di tengah masyarakat. Sehingga majelis taklim dapat dikatakan bagian dari aktivitas masyarakat untuk mengisi pengetahuan kaum muslimah. Kemudian berangkat dari hal tersebut majelis taklim merupakan fenomena universal, namun pada aspek lokal ia merupakan sebuah kekhasan Nusantara yang diproduksi berdasarkan kultur umat Islam Indonesia. ${ }^{59}$

Syair pengajian ini awalnya hanya pembacaan yasin, dikarenakan para jemaah telah mahir atau bisa membaca yasin

55 Wawancara, Ustadzah Ama Kalsum.

56 Hadi Machmud, "Model Pendidikan Pada Majelis Taklim Kota Kendari," Al-Izzah 8, no. 1 (2013): 73.

${ }^{57}$ Muhammad Yusuf Pulungan, "Peran Majelis Taklim Dalam Membina Keluarga Sakinah Masyarakat Muslim Di Kota Padangsidimpuan," Tarkir 9, no. 1 (2014): 136.

58 Muchlis M. Hanafi, ed., Pembangunan Generasi Muda (Tafsir Al-Qur'an Tematik) (Jakarta: Lajnah Pentashihan Mushaf Al-Qur'an, 2011), 81.

59 Iskandar, Azra, and Muhammad Hisyam, Sejarah Kebudayaan Islam Indonesia Jilid 3, 415. 
maka dialihkan pada pembacaan syair, amalan, selawat, doa dari kitab Sullamu at-Taufiq, kitab perukunan, rukun yang dua puluh; wajib dan mustahil. Selain itu juga mempelajari hal-hal yang termasuk dalam pembahasan awwaluddin dalam mempersiapkan ibadah, seperti rukun sembahyang, fardhu sembahyang, dan lain sebagainya. Setelah hal tersebut dipahami oleh jemaah, kemudian ustadzah mengajarkan hal lain seperti kutipan berikut:

Kini ko lah ke ujung tu lah doa-doa bae lagi, sudah tu macam-macam amalan kan. ${ }^{60}$

Jemaah atau ustadzah yang mengajarkan pada majelis taklim tersebut menyebutnya sebagai syair pengajian. Disusun, ditulis dan dikutip dari berbagai kitab, kitab hadis, dan al-Quran. Setelah Ustadzah Ama Kalsum menyalin, kemudian dibagikan kepada anggota majelis taklim untuk dibaca bersama di setiap kali pengajian dilaksanakan. ${ }^{61}$ Ama Kalsum merupakan seorang pengajar pada majelis taklim tersebut yang sudah puluhan tahun terjun ke dalam dunia dakwah dan menghadapi berbagai dinamika masyarakat.

Bacaan doa yang dilantunkan di saat sebelum ceramah agama yaitu: doa pengampunan dosa, doa sesudah salah subuh, doa menghilangkan kantuk, doa untuk anak baru lahir, doa kalau rumah hendak pengajian, doa memasuki rumah, doa mulai memakai pakaian, doa pakaian setelah dipakai, doa memakai pakaian baru, doa duduk dalam majelis pengajian atau di rumah, doa pulang majelis, doa keselamatan untuk anak dan cucunya, doa memohon syafaat kepada Rasulullah dan doa kedua orang tua. ${ }^{62}$ Begitu juga dengan amalan, berbagai macam yang dibaca pada saat syair pengaiian berlangsung seperti amalan untuk isi rumah di surga, amalan di malam Jumat dan amalan lainnya. ${ }^{63}$ Sedangkan

\footnotetext{
${ }^{60}$ Wawancara, Ustadzah Ama Kalsum.

${ }^{61}$ Wawancara, Mawaddah, 18 Oktober 2020.

${ }^{62}$ Ama Kalsum, "Dokumen Syair Pengajian," n.d.

${ }^{63}$ Kalsum.
} 
selawat yang terdapat dalam syair tersebut ialah selawat Nabi yang dibaca ketika salat, selawat hari Jumat di waktu asar, selawat yang tertulis di batu gua Hira', dan selawat sekalian diampuni dosa. ${ }^{64}$

Aktivitas majelis taklim di Desa Pangedaran dilakukan secara teratur di setiap kali pengajian dilaksanakan, dimulai membaca doadoa, amalan-amalan, selawat, menjelaskan hadis, tata cara salat, dan diakhiri dengan ceramah agama dari Ustadzah Ama Kalsum. Kitab yang digunakan adalah Durratu al-Nashibin. Kebiasaan ini dilakukan secara rutin, hingga masuk bulan Sya'ban anggota majelis taklim melakukan puasa bersama pada 10 hari sebelum puasa Ramadhan datang. ${ }^{65}$ Maka tidak dapat dinafikan jika dakwah melalui majelis taklim tampak efektif dan berpotensi besar dalam memeriahkan dakwah Islam. ${ }^{66}$

Rutinitas demikian adalah upaya mengingat Tuhan dan mendekatkan diri kepada Allah, permintaan taubat hingga konsisten di jalan yang benar agar tidak menyimpang dari syariat Islam. ${ }^{67}$ Pengelolaan dan pengendalian batin jemaah melalui ritualritual lahiriah agar memperoleh refleksi secara batin dan mampu menjadi pribadi muslimah yang kokoh dalam ajaran agama Islam dan tetap konsisten bermunajat kepada Allah Swt. Pada konteks ini majelis taklim dapat dijuluki sebagai sentral pembelajaran Islam yang tidak kalah perannya dalam membentuk manusia cerdas dan berakhlak. ${ }^{68}$ Meningkatkan kualitas spiritual dalam Islam mendapat

${ }^{64}$ Kalsum.

${ }^{65}$ Wawancara, Ustadzah Ama Kalsum.

66 Iskandar, Azra, dan Muhammad Hisyam, Sejarah Kebudayaan Islam Indonesia Jilid 3, 413.

${ }^{67}$ Wawancara, Ketua Majelis Taklim.

68 Kalsum Minangsih, "Paradigma Baru Pengelolaan Institusi Dakwah: Urgensi Ilmu Manajemen Mewujudkan Majelis Taklim Ideal," Kontekstualita 29, no. 2 (2014): 145-57. 
perhatian lebih sejak usia dini, hal demikian adalah usaha untuk menanam keimanan dan keruhanian secara kuat. ${ }^{69}$

Merawat ruhani jemaah melalui doa-doa sejalan dengan tujuan dakwah yaitu memperbaiki jiwa manusia, menebarkan kasih sayang, menjaga persatuan dan persaudaraan. ${ }^{70}$ Solidaritas jemaah dalam membangun tradisi intelektual melalui majelis taklim berguna bagi keberlanjutan dakwah Islam dalam kehidupan masyarakat. ${ }^{71}$ Masyarakat yang sepi dari kehadiran ustadz, pengajar, atau tokoh agama akan merasakan kehampaan dari kekosongan spiritual atau kekeringan ruhani. Hal ini sangat berdampak besar, bagaimana Desa tersebut telah dikenal bagi masyarakat sekitar sebagai Desa yang memiliki angka pendidikan terendah, moralitas yang buruk, serta pergaulan anak muda tidak terkontrol di tengah arus perkembangan zaman dan kemajuan teknologi.

Maka kehadiran majelis taklim di desa ini berfungsi dan berperan penting bagi umat Islam. Peranan yang diperlukan di desa ini seperti; ${ }^{72}$ pertama, menguatkan fungsi majelis taklim sebagai pendidikan non formal yang dapat mengisi pengetahuan masyarakat dalam hal pokok ajaran Islam, persoalan kehidupan sehari-hari, dan amalan-amalan lainnya. Kedua, menjadikan majelis taklim sebagai tempat pengkaderan generasi Islam. Ketiga, menjadikan majelis taklim rumah konseling. Keempat, menjadi tempat pengembangan skill jemaah. Kelima, memberdayakan masyarakat pada aspek ekonomi dan sosial. Keenam, menjadi ruang silaturrahmi fisik dan ruhani. Ketujuh, menjadi pusat informasi dan

69 Muchlis. M. Hanafi, ed., Pendidikan, Pembangunan Karakter, Dan Pengembangan Sumber Daya Manusia (Tafsir Al-Qur'an Tematik) (Jakarta: Lajnah Pentashihan Mushaf Al-Qur'an, 2010), 357.

${ }^{70}$ Bahrum Subagia, Fikih Dakwah \& Pemikiran Dakwah Di Indonesia (Bogor: Pustaka Melek, 2013), 11.

71 Fahrurrozi, Model-Model Dakwah Di Era Kontemporer (Mataram: LP2M UIN Mataram, 2017), 50.

72 Maryam, "Peran Majelis Ta'lim Nurul Iman Dalam Pembentukan Sikap Keagamaan Masyarakat RT 10/02 Kelurahan Pagar Dewa Kec Selebar Bengkulu," Manhaj: Jurnal Penelitian Dan Pengabdian Masyarakat 3, no. 2 (2018): 29-31. 
komunikasi. Kedelapan, menjadi tempat pengembangan budaya Islam. Kesembilan, menjadi lembaga kontrol sosial.

Dengan demikian peranan di atas dapat memaksimalkan aktivitas penting dalam mendukung kerja-kerja majelis taklim mendakwahkan Islam dan mematangkan spiritualitas jemaah. Majelis taklim terbukti telah terlibat dalam menangkal kehampaan agama, penyederhanaan pemahaman keagamaan dan pandangan tekstual-rigid di dalam komunitas muslim yang belakangan dekat dengan framing radikalisme. ${ }^{73}$ Dalam berdakwah tentu penilaian terhadap seorang jemaah atau manusia secara umum tidak cepat mengambil pilihan baik-buruk, halal-haram, atau berdosa dan berpahala, itu berarti pandangan terhadap manusia ditunda dan memberi tawaran perspektif lain.

Amalan-amalan pada majelis taklim di Desa Pangedaran adalah bagian aktivitas ruhani seorang manusia atau jemaah secara alamiah yang digerakkan oleh fisik sebagai media dalam mengaktifkan alam bawah sadar dan didikte oleh kegiatan kolektif suatu komunitas. Pengajian ini memberi ruang untuk mengolah batin jemaah secara bersama dengan mengingat Tuhan dan meminta ampunan atas segala kesalahan atau perbuatan yang dilarang dalam agama. Berbagai macam doa, selawat, dan amalan yang mengarah pada hal demikian telah dilakukan oleh setiap anggota sebagai bentuk perawatan terhadap ruhani jemaah.

Hal demikian sedikit berbeda dengan kalangan muslim kelas menengah di perkotaan. Seperti kasus umat muslim di Surakarta, religiusitas mereka diperlihatkan melalui aktivitas majelis taklim yang memadukan kegiatan spiritual dan sosial. Bentuk lain ekspresi keagamaan masyarakat muslim perkotaan ialah gaya hidup yang syar'i dengan memilih atau menampilkan produk serta jasa berlabel

${ }^{73}$ Wiwi Siti Sajaroh dan Sarah Hajar Mahmudah, "NU Women's Role In Narrating The Moderate Islam Through Majelis Taklim," Advances in Social Science, Education and Humanities Research (ASSEHR) 129 (2018), 375. 
syariah maupun Islami. ${ }^{74}$ Kekeringan spiritual memang menuntut umat Islam baik secara kelembagaan, individu maupun kelompok agar cepat menangkap kebutuhan masyarakat muslim, hal ini tentu sesuai kebutuhan umat Islam di tengah krisis spiritual. Salah satu kegiatan rutin yang dapat dilakukan ialah melalui majelis taklim untuk berdakwah secara langsung kepada masyarakat. ${ }^{75}$

Masyarakat muslim perkotaan menjadi pintu gerbang dari arus modernisasi yang berdampak besar bagi kehidupan sosial dan kegersangat spiritual. Hal demikian akhirnya mencari alternatif untuk mencari pelampiasan sementara atau untuk merespon terhadap kegelisahan batin. Sebagaimana terlihat dalam kutipan berikut:

Berkumpul di majelis taklim, bukan hanya mencari ilmu agama dan pahala, namun juga sebagai peneduhan diri dalam mencari ketenangan. Bagi masyarakat perkotaan yang berada dalam budaya industrialisasi di mana cenderung individualis, kehidupan masyarakat urban yang identic dengan anomie. Perasaan anomi menurut E. Durkheim dapat menggangu stabilitas sosial masyarakat. ${ }^{76}$

Hal ini sesuai dengan kehidupan masyarakat modern yang sedang mapan, bahwa agama adalah suatu struktur institusi penting yang dapat melengkapi sistem sosial. ${ }^{77}$ Maka agama sebagai identitas menjadi modal sosial dapat mempengaruhi ikatan yang kuat. Setiap individu pandangannya akan dipengaruhi oleh kekuatan dan kemampuan supranatural atau spiritualitas seorang manusia. Karena agama adalah sumber keyakinan sosial, ia tidak

\footnotetext{
${ }^{74}$ Nurul Aeni dan Lilam Kadarin Nuriyanto, "Religiusitas Kelas Menengah Muslim Surakarta (Interaksi Dengan Globalisasi Dan Modernitas)," Harmoni: Jurnal Multikultural \& Multireligius 19, no. 2 (2020): 232.

${ }^{75}$ Syamsul Akbar, "Majelis Taklim Nahdliyah Kraksaan Layani Kebutuhan Spiritual Warga," nuonline, 2017, https://www.nu.or.id.

${ }^{76}$ Umdatul Hasanah, "Majelis Taklim Perempuan Dan Pergeseran Peran Publik Keagamaan Pada Masyarakat Perkotaan Kontemporer" (Jakarta, 2016), 123.

77 Muhammad Fajar Pramono, Sosiologi Agama Dalam Konteks Indonesia (Ponorogo: UNIDA Gontor Press, 2017), 123.
} 
tumbuh secara alamiah melainkan proses panjang anggota masyarakat. $^{78}$

Spiritualitas anggota jemaah adalah sebuah hasil interaksi dan internalisasi dari berbagai pengetahuan maupun pengalaman keagamaan sebagaimana pada ritualitas yang dilakukan dalam pelaksanaan pengajian. Setiap anggota tentu mengalami ekspresi keagamaan secara individu maupun kolektif. Hubungan antar anggota pengajian yang memiliki persamaan pandangan terhadap kehidupan atau kebutuhan pengetahuan keagamaan dan kerohanian mendorong mereka untuk masuk ke dalam satu komunitas majelis taklim. Menurut Tonnies kelompok seperti mereka adalah jenis kelompok gemeinschaft of mind, ${ }^{79}$ yang mana persahabatan, serta persamaan kebutuhan menjadi alasan untuk berhubungan dan berinteraksi secara teratur.

\section{Penutup}

Ruhani jemaah merupakan identitas manusia sebagai makhluk yang memiliki kesadaran spiritual menjadi ide dasar dari pengajian majelis taklim di Desa Pangedaran ini. Kesadaran ruhani menjadi penangkal bagi jemaah untuk mengikuti arus konsumerisme di kalangan masyarakat modern sebagaimana terjadi pada majelis taklim kaum muslim urban. Pembahasan dan diskusi di atas menyimpulkan bahwa kegiatan dakwah di Desa Pangedaran melalui majelis taklim konsisten dilakukan sebagai kepedulian dan keprihatinan terhadap realitas masyarakat muslimah desa banyak yang tidak mampu membaca huruf Arab, mengaji dan kekeringan spiritual atau keadaan ruhani jemaah yang tidak stabil. Majelis taklim telah memainkan peran penting dalam memberi pendidikan keislaman dan memelihara spiritualitas bagi kaum muslimah

78 Haryanto Sindung, Sosiologi Agama: Dari Klasik Hingga Postmodern (Yogyajarta: Ar-Ruzz Media, 2015).

${ }^{79}$ Nurani Soyomukti, Pengantar Sosiologi: Dasar Analisis, Teori \& Pendekatan Menuju Analisis Masalab-Masalab Sosial, Perubahan Sosial, \& Kajian-Kajian Strategis (Yogyajarta: Ar-Ruzz Media, 2014), 300. 
As'ad, Muhammad Rafii, Abdurahman Syayuthi, Fahmi Rohim

dewasa dan mengisi kehausan ruhani bagi jemaah majelis taklim. Hal demikian sebagaimana terlihat bahwa dalam pengajian tersebut tidak diperkenankan membuat arisan dan baju seragam, makanan berlebihan, dan honor bagi ustadzah. Pengajian yang dilakukan secara konsisten berhasil merawat ruhani jemaah dari berbagai arus modernisasi, demoralisasi dan di tengah lingkungan minim pengetahuan keagamaan baik bagi anak-anak muda maupun perempuan muslim tua. Dengan rutinitas pengajian, kerohanian masyarakat muslimah dapat terawat dan mampu mengontrol diri dari setiap persoalan terlarang dalam Islam.

\section{Daftar Pustaka}

Aeni, Nurul, and Lilam Kadarin Nuriyanto. "Religiusitas Kelas Menengah Muslim Surakarta (Interaksi Dengan Globalisasi Dan Modernitas)." Harmoni: Jurnal Multikultural \& Multireligius 19, no. 232 (2020).

Agus Ahmad Safei. Sosiologi Dakwah: Rekonsepsi, Revitalisasi, Dan Inovasi. Yogyajarta: Deepublish, 2016.

Ahmad Darlis. "Hakikat Pendidikan Islam: Telaah Antara Hubungan Pendidikan Informal, Non Formal Dan Formal." Jurnal Tarbiyah XXIV, no. 1 (2017): 84-103.

akb. "KUA Kec Pauh Memberikan Bimbingan Majelis Taklim." Kantor Wilayah Kementerian Agama Provinsi Jambi, 2013. https://jambi.kemenag.go.id.

Anitasari, Dini, Fatimah Hasan, Lely Nurohmah, and Sri Wiyanti. "Perempuan Dan Majelis Taklim: Membicarakan Isu Privat Melalui Ruang Publik Agama Penulis :," no. April (2010).

Asep Ahmad Fathurrohman. Ilmu Pendidikan Islam Sebuab Pengantar (Dengan Pendekatan Teologis Dan Filosofis). Bandung: Pustaka Al-Kasyaf, 2013.

Asnil Aidah Ritonga, and Mahariah. "Majelis Taklim Sebagai Sebuah Lembaga Pendidikan." Al-Kaffah 2, no. 2 (2014): 143-76.

Aspari Ismail. Penguatan Pendidikan Islam Informal Dan Non Formal.

330 | TAJDID vol. 20, No. 2, Juli - Desember 2021 
Edited by Moh. Haitami. Pontianak: Bulan Sabit Press, 2016. Bahrum Subagia. Fikih Dakwah \& Pemikiran Dakwah Di Indonesia. Bogor: Pustaka Melek, 2013.

Bustanol Arifin. "Strategi Komunikasi Dakwah Da'i Hidayatullah Dalam Membina Masyarakat Pedesaan." Communicatus: Jurnal Ilmu Komunikasi 2, no. 2 (2018): 159.

Fahrurrozi. Model-Model Dakwah Di Era Kontemporer. Mataram: LP2M UIN Mataram, 2017.

Fathur Rohman. "Strategi Da'i Dalam Menyampaikan Nilai-Nilai Keislaman (Studi Majelis Ta'lim Nurul Yakin Desa Pauh Kecamatan Pauh Kabupaten Sarolangun Jambi)." Jambi, 2018.

Firman Nugraha. "Majelis Taklim Sebagai Basis Pemberdayaan Umat." Jurnal Diklat Keagamaan XII, no. 33 (2018): 105-13.

Fitriyah, Hanny, Darmi AR, and Rakhmad Zailani Kiki. Manajemen \& Silabus Majelis Taklim. Jakarta Utara: Pusat Pengkajian dan Pengembangan Islam Jakarta (Jakarta Islamic Centre), 2012.

Hadi Machmud. "Model Pendidikan Pada Majelis Taklim Kota Kendari." Al-Izzah 8, no. 1 (2013): 73.

Hasanah, Umdatul. Majelis Taklim Perempuan Dan Perubahan Sosial Pada Masyarakat Perkotaan. Magelang: PKBM "Ngudi Ilmu," 2017.

Helmawati. "Meningkatkan Pendidikan Perempuan Indonesia Melalui Optimalisasi Majelis Ta'lim." INSANCITA: Journal of Islamic Studies in Indonesia and Southeast Asia 3, no. 1 (2018): 65-88.

Henda. Panduan Umum Majelis Ta'lim. Jawa Barat: Yayasan AMMA, 2010.

Iskandar, Muhammad, Azyumardi Azra, and Muhammad Hisyam. Sejarah Kebudayaan Islam Indonesia Jilid 3. Jakarta: Direktorat Sejarah dan Nilai Budaya, Direktorat Jenderal Kebudayaan, Kementerian Pendidikan dan Kebudayaan, 2015.

Kalsum, Ama. "Dokumen Syair Pengajian," n.d.

Kalsum Minangsih. "Paradigma Baru Pengelolaan Institusi 
As'ad, Muhammad Rafii, Abdurahman Syayuthi, Fahmi Rohim

Dakwah: Urgensi Ilmu Manajemen Mewujudkan Majelis Taklim Ideal." Kontekstualita 29, no. 2 (2014): 145-57.

M.Iqbal Irham. Rasa Rubani: Spiritualitas Di Abad Modern. Bandung:

Citapustaka Media Perintis, 2012.

Malini, Ni Luh Nyoman Seri. Analisis Wacana: Wacana Dakwah Di Kampung Muslim Bali. Denpasar-Bali: Cakra Press, 2016.

Maryam. "Peran Majelis Ta'lim Nurul Iman Dalam Pembentukan Sikap Keagamaan Masyarakat RT 10/02 Kelurahan Pagar Dewa Kec Selebar Bengkulu." Manhaj: Jurnal Penelitian Dan Pengabdian Masyarakat 3, no. 2 (2018).

Mega Lestari Ningsih. "Urgensi Dakwah Dalam Pembinaan Akhlak Jamaah Di Majlis Taklim Al-Hidayah Desa Keranggan Kecamatan Sekernan Kabupaten Muaro Jambi.” Jambi, 2020.

Mubarok, and Made Dwi Andjani. Komunikasi Antarpribadi Dalam Masyarakat Majemuk. Jakarta Timur: Dapur Buku, 2014.

Muchlis. M. Hanafi, ed. Pendidikan, Pembangunan Karakter, Dan Pengembangan Sumber Daya Manusia (Tafsir Al-Qur'an Tematik). Jakarta: Lajnah Pentashihan Mushaf Al-Qur'an, 2010.

Muchlis M. Hanafi, ed. Etika Berkeluarga, Bermasyarakat, Dan Berpolitik (Tafsir Al-Qur'an Tematik). Jakarta: Lajnah Pentashihan Mushaf Al-Qur'an, 2009. -, ed. Pembangunan Generasi Muda (Tafsir Al-Qur'an Tematik). Jakarta: Lajnah Pentashihan Mushaf Al-Qur'an, 2011.

- ed. Spiritualitas Dan Akblak (Tafsir Al-Qur'an Tematik). Jakarta Timur: Lajnah Pentashihan Mushaf Al-Qur'an, 2012.

Muhammad Fajar Pramono. Sosiologi Agama Dalam Konteks Indonesia. Ponorogo: UNIDA Gontor Press, 2017.

Muhammad Yusuf Pulungan. "Peran Majelis Taklim Dalam Membina Keluarga Sakinah Masyarakat Muslim Di Kota Padangsidimpuan." Tazkir 9, no. 1 (2014): 136.

Mujahidin. "Urgensi Majelis Taklim Sebagai Lembaga Dakwah Di Masyarakat." Jurnal Alhadharah 17, no. 33 (2018): 1-12.

Mukhibat. "Rekonstruksi Spirit Harmoni Berbasis Masjid (Studi

332 | TAJDID vol. 20, No. 2, Juli - Desember 2021 
Kasus KPM Tematik Posdaya Di Kecamatan Pulung Kabupaten Ponorogo)." In Memahami Realitas Sosial Keagamaan, edited by Raudatul Ulum, 185. Puslitbang

Kehidupan Keagamaan Badan Litbang dan Diklat Kementerian Agama RI, 2015.

Nisaul Fadillah. "Female Brokers: Mobilising Voters within Indonesia's Majelis Taklim Network." Global Media Journal Australian 14, no. 1 (2020): 12.

Noer, Khaerul Umam. "Majelis Taklim Perempuan Dan Transformasi Otoritas Keagamaan Dalam Perspektif Feminist Anthropology." Surabaya, 2009.

Nurani Soyomukti. Pengantar Sosiologi: Dasar Analisis, Teori \& Pendekatan Menuju Analisis Masalah-Masalah Sosial, Perubahan Sosial, \& Kajian-Kajian Strategis. Yogyajarta: Ar-Ruzz Media, 2014.

Kantor Wilayah Kementerian Agama Provinsi Jambi. "Pengumuman Tentang Bantuan Operasional Majelis Taklim," 2020. http://jambi.kemenag.go.id.

Putri, Givani Anisa, Imron A. Hakim, and Evy Ratna Kartika Wati. "Dinamika Kelompok Pada Majelis Taklim Jami'atul Muslimah Di Desa Mataram Kabupaten Musi Rawas." Journal of Nonformal Education and Community Empowerment 3, no. 1 (2019): 44-51.

Qadaruddin, Muhammad, A.Nurkidam, and Firman. "Peran Dakwah Masjid Dalam Peningkatan Kualitas Hidup Masyarakat." Ilmu Dakwah: Academic Journal for Homiletic Studies 10, no. 2 (2016): 237.

Qibtiyah, Alimatul. "Pengakuan Ulama Dan Isu Perempuan Di Majlis Trajih Dan Tajdid Muhammadiyah." In Demokratisasi Fatwa, Diskursus, Teori Dan Praktik, edited by Syafiq Hasyim, 193-211. Tangerang Selatan: International Center for Islam and Pluralism (ICIP), 2018.

Rosyidi. Dakwah Sufistik Kang Jalal: Menentramkan Jiwa, Mencerabkan Pikiran. Jakarta: Paramadina, 2004.

Rumadani Sagala. "Peran Majelis Taklim Al-Hidayah Dalam 
As'ad, Muhammad Rafii, Abdurahman Syayuthi, Fahmi Rohim

Pendidikan Islam Dan Gerakan Sosial Keagamaan Di Propinsi Lampung." AL-MURABBI: Jurnal Studi Kependidikan Dan Keislaman 6, no. 1 (2019): 27-36.

S. Hamdani. "Tasawuf Sebagai Bahan Terbaik Dakwah.” Jakarta, 2006.

Saeful Lukman, Yusuf Zaenal Abidin, Asep Shodiqin. "Peranan Majelis Taklim Dalam Meningkatkan Pemahaman Keagamaan Masyarakat." Tabligh: Jurnal Komunikasi Dan Penyiaran Islam 4, no. 1 (2019): 65.

Sahdin Hsb. Politik Arabisasi Dan Dakwah: Refleksi Perkembangan Dakwah Era Umaiyah Dan Upaya Kontekstualisasi Dakwah Kontemporer Di Indonesia. Medan: Perdana Publishing, 2019.

Sajaroh, Wiwi Siti, and Sarah Hajar Mahmudah. "NU Women's Role In Narrating The Moderate Islam Through Majelis Taklim." Advances in Social Science, Education and Humanities Research (ASSEHR) 129 (2018).

Sindung, Haryanto. Sosiologi Agama: Dari Klasik Hingga Postmodern. Yogyajarta: Ar-Ruzz Media, 2015.

SM. "Emak-Emak Majelis Taklim Kota Jambi Berikan Dukungan Ke Fachrori-Syafril.” Jamberita.com, 2020. https://jamberita.com/read/2020/11/12/5963585/emake mak-majelis-taklim-kota-jambi-berikan-dukungan-kefachrorisyafril/.

Srinarwati, Dwi Retnani, Pinky Saptandari Endang Pratiwi, and Diah Ariani Arimbi. "Simulacra in Women's Majelis Taklim Based on Jean Baudrillard's Perspective." JURNAL STUDI KOMUNIKASI 4, no. 3 (2020).

Suhirman, Rini Fitria, and Fathan Awwalur Rayyan. "Dakwah Subuh Dan Filantropi Islam: Praktik Terbaik Pembelajaran Dakwah Di Era Millenial." Jurnal Ilmiah Syiar 20, no. 1 (2020): 63-71.

Syamsuddin. Pengantar Sosiologi Dakwah Edisi Pertama. Jakarta: Kencana, 2016.

Syamsul Akbar. "Majelis Taklim Nahdliyah Kraksaan Layani Kebutuhan Spiritual Warga." nuonline, 2017. 
https://www.nu.or.id.

Umdatul Hasanah. "Majelis Taklim and the Shifting of Religious Public Role in Urban Areas." Ilmu Dakwah: Academic Journal for Homiletic Studies 13, no. 1 (2019): 97.

. "Majelis Taklim Perempuan Dan Pergeseran Peran Publik Keagamaan Pada Masyarakat Perkotaan Kontemporer." Jakarta, 2016.

W. Lawrence Neuman. Social Research Methods: Qualitative and Quantitative Approaches. 7th ed. Boston: Pearson Education, 2011.

Waryono Abdul Ghafur. "Dakwah Dan Interaksi Interkultural.” In Dakwah Humanis, edited by Muhammad Habibi Siregar and Joko Susanto, 315. Bandung: Citapustaka Media, 2014.

Yazid, Yasril, and Nur Alhidayatillah. Dakwah Dan Perubahan Sosial. Jakarta: PT RajaGrafindo Persada, 2017. 